\title{
Stavovi nastavnika i učenika glazbene škole o poštivanju participativnih prava učenika u nastavi sviranja glazbenog instrumenta
}

Davor Brđanović*

davor.brdanovic@skole.hr

\author{
https://doi.org/10.31192/np.17.3.11 \\ UDK: 341.231.14-057.874 \\ 37.018.54:78(497.5Varaždin) \\ Prethodno priopćenje / Preliminary communication \\ Primljeno: 2. kolovoza 2019. \\ Prihvaćeno: 5. rujna 2019.
}

Tema su ovog rada prava učenika u glazbenoj školi, posebice na sudjelovanje $i$ uvažavanje njihova mišljenja u nastavi sviranja instrumenta. U istraživanju je sudjelovalo 206 ispitanika, 53 nastavnika i 153 učenika Glazbene škole u Varaždinu. S postojanjem posebnih prava djece u odnosu na odrasle slaže se 56,86 $\%$ anketiranih učenika $i 66,04 \%$ nastavnika. Konvenciju koja štiti dječja prava točno navodi 1,96 \% učenika (85,62 \% ih za nju ne zna) i 30,20 \% nastavnika (43,40\% ih za nju ne zna). Ni jedno specifično dječje pravo ne može navesti 28,76 \% učenika i 43,40 \% nastavnika. Ǔ̌enici statistički značajno više od učenica iskazuju da su im u školi važnija prava od dužnosti (odgovornosti), a statistički značajne razlike između nastavnika $i$ učenika pokazale su se kod stavova: svako dijete ima pravo na glazbeno obrazovanje, kada se poštuju učenička prava nastava sviranja je kvalitetnija (više procjene daju učenici); učenici ne sudjeluju u planiranju svog sviračkog razvoja, učenici uvijek biraju barem jednu skladbu koju sviraju, mišljenje učenika o sviranju se ne uvažava (više procjene daju nastavnici). Učenici i nastavnici većinom su zadovoljni ostvarivanjem dječjih prava u glazbenoj školi premda nisu s njima dovoljno upoznati, što upućuje na potrebu snažnijeg rada i jednima is drugima na tom području. Iako se dječja prava u glazbenoj školi uvelike poštuju, prostora za poboljšanja i dalje ima.

Ključne riječi: glazba, Glazbena škola u Varaždinu, nastava glazbe, prava djeteta, suradnička nastava.

\footnotetext{
* Dr. sc. Davor Brđanović, prof. mentor, Glazbena škola u Varaždinu, Kapucinski trg 8, HR42000 Varaždin.
} 


\section{Uvod}

Potreba za osnivanjem međunarodne organizacije koja bi imala utjecaj, snagu i sposobnost sprečavati buduće ratne sukobe u svijetu, sazrela je tijekom Drugoga svjetskog rata pa su na tragu ideala i principa Francuske revolucije - sloboda, jednakost, bratstvo - osnovani Ujedinjeni narodi (UN). Na konferenciji u San Franciscu 26. lipnja 1945., Povelju UN-a potpisalo je 50 zemalja te je ona 24. listopada 1945. stupila na snagu. Osim ostvarivanja temeljnog cilja - sačuvati buduće generacije od rata - pred UN-om je kao važna zadaća postavljeno promicanje temeljnih prava, dostojanstva i vrijednosti čovjeka te osiguravanje ravnopravnosti velikih i malih naroda. ${ }^{1} \mathrm{U}$ nastojanju normiranja ljudskih prava te utvrđivanja mehanizama njihove provedbe i zaštite, Glavna skupština UN-a usvojila 10. prosinca 1948. Opću deklaraciju o ljudskim pravima. ${ }^{2}$ Budući da Deklaracija nije bila obavezujući dokument, njezina su načela ozakonjena Međunarodnim ugovorom o građanskim i političkim pravima i Međunarodnim ugovorom o ekonomskim, socijalnim i kulturnim pravima. Oni su na snazi od 1976. godine, a 1991. ratificirani su i u Hrvatskoj. ${ }^{3}$ Tijekom godina, vrijednosti Opće deklaracije o ljudskim pravima ugrađene su u dokumente različitih međunarodnih institucija, ${ }^{4}$ ali je i dalje nužno razvijati svijest i znanja o pravima čovjeka i omogućiti još većem broju ljudi da ta prava i ostvare jer je razlika između poželjnog i stvarnog stanja ${ }^{5}$ velika.

Prava djeteta poseban su dio ljudskih prava. Sva djeca trebaju uživati sretno, mirno i sigurno djetinjstvo ispunjeno igrom i učenjem. ${ }^{6}$ Prvi međunarodni dokument koji se bavi pravima i zaštitom djece, Ženevsku deklaraciju, donijela je Liga naroda 1924. Ona ima pet ciljeva: osigurati djeci uvjete za normalan razvoj te dom, hranu i zdravstvenu zaštitu, zatim sigurnost, zaštitu od iskorištavanja i odgoj koji će razviti dječji potencijal na dobrobit zajednice. ${ }^{7}$ Deklaracija Ujedinjenih naroda o pravima djeteta iz 1959., svojevrsna nadopuna Opće deklaraci-

${ }^{1}$ Usp. UJEDINJENI NARODI, Povelja Ujedinjenih naroda, UN Dag Hammarskjöld Library, http://dag.un.org/handle/11176/387329 (18.07.2019); Hrvoje VRGOČ, Vrijeme je za mir, poštovanje čovjekovih prava i demokraciju, u: Hrvoje VRGOČ (ur.), Odgoj i obrazovanje za život u demokratskom društvu, Zagreb, HPKZ, 1997, 9-19.

${ }^{2}$ Usp. UJEDINJENI NARODI, Opća deklaracija o ljudskim pravima, https://www.un.org/en/ universal-declaration-human-rights/index.html (15.03.2019); Vrgoč, Vrijeme je za mir...

${ }^{3}$ Usp. MVEP, Multilateralni odnosi, http://www.mvep.hr/hr/vanjska-politika/multilateralniodnosi-staro-ijvhj/ujedinje ni-narodi-(un)/ljudska-prava-u-rh/\#3 (01.08.2019).

${ }^{4}$ Vedrana SPAJIĆ-VRKAŠ, Globalna etika, kulturni pluralizam, demokracija, u: Vrgoč (ur.), Odgoj $i$ obrazovanje..., 40.

5 Usp. Vrgoč, Vrijeme je za mir...

${ }^{6}$ Usp. Dubravka MALEŠ, Ivanka STRIČEVIĆ, Dječja prava kao temelj ljudskih prava, u: Vrgoč (ur.), Odgoj i obrazovanje...

${ }^{7}$ Usp. Gordana KUTEROVAC-JAGODIĆ i dr. (ur.), Poimanje djeteta i percepcija dječjih prava u Hrvatskoj. Rezultati empirijskog istraživanja Ljetne psihologijske škole studenata i nastavnika Odsjeka za psihologiju Filozofskog fakulteta Sveučilišta u Zagrebu. Umag, 2000, Zagreb, FFZG, 2003. 
je o ljudskim prvima, u deset načela čini korak naprijed u zaštiti i unapređenju prava djece te definira njihova građanska, zakonska, ekonomska, socijalna, zdravstvena i kulturna prava. Preciznija i šira od Ženevske deklaracije, u skladu $\mathrm{s}$ vremenom u kojem je nastala, Deklaracija o pravima djeteta govori o potrebi posebne pažnje i brige o djeci, što je zadaća i roditelja i šire društvene zajednice, radi poboljšanja položaja mladih u društvu. ${ }^{8}$

Budući da su obje deklaracije neobavezujuće, više su preporuke za države i vlade, sedamdesetih godina prošlog stoljeća uočeno je da one ne mogu stvarno zaštititi djecu. Stoga su 20. studenog 1989. UN donijeli Konvenciju o pravima djeteta. ${ }^{9}$ Konvencija je pravni akt sa snagom zakona te obvezuje zemlje potpisnice na njezinu primjenu, a do danas su je potpisale gotovo sve svjetske zemlje. ${ }^{10}$

Potpisivanjem Konvencije o pravima djeteta 1991., Hrvatska je prihvatila obvezu promicanja i ostvarivanja prava djece prema visokim međunarodnim standardima pa su ta prava na različite načine regulirana i ugrađena u brojne hrvatske propise i dokumente. ${ }^{11}$

\section{Pravo na obrazovanje, uvažavanje mišljenja i sudjelovanje u školi}

Univerzalno pravo na obrazovanje zapisano u Općoj deklaraciji o ljudskim pravima pobliže razrađuje Konvencija o pravima djeteta. U 28. članku Konvencije države se, primjerice, obvezuju na organiziranje obveznog i besplatnog osnovnog obrazovanja, na poduzimanje mjera za poticanje redovitog dolaska na nastavu i smanjenja stope ispisa iz škole itd. U 29. članku govori se, među ostalim, o tome da obrazovanje djeteta treba biti usmjereno punom razvoju njegove osobnosti, nadarenosti, duševnih i tjelesnih sposobnosti, poštivanju ljudskih prava i sloboda te životu u različitosti, miru, ravnopravnosti i prijateljstvu. Osim prava na obrazovanje, od 12. do 17. članka Konvencija propisuje pravo djeteta na uvažavanje njegova mišljenja, na sudjelovanje pa i na aktivno sudjelovanje u obrazovnom procesu. Članak 12. u prvoj točki traži od država da djetetu koje je u stanju oblikovati vlastito mišljenje, osigura pravo na slo-

\footnotetext{
${ }^{8}$ Usp. isto.

9 Usp. UN, Konvencija o pravima djeteta, https:/www.unicef.hr/wp-content/uploads/2017/05/ Konvencija_20o_20pravima_20djeteta_full.pdf (21.03.2019); UNICEF, Konvencija o pravima djeteta, https://www. unicef.hr/konvencija-o-pravima-djeteta/ (10.07.2019).

${ }^{10} \mathrm{U}$ Konvenciji su definirana prava djeteta, pri čemu se djetetom smatraju svi mlađi od 18 godina. Ona sadrži 54 članka temeljena na načelima nediskriminacije, najboljem interesu djeteta, pravu na život, postanak i razvoj te pravu na vlastito mišljenje u skladu s dobi i zrelošću, pa se stoga prava iz Konvencije, s obzirom na područje na koje se odnose mogu podijeliti na prava preživljavanja, razvojna prava, zaštitna prava i prava sudjelovanja.

${ }^{11}$ Usp. PRAVOBRANITELJ ZA DJECU RH, Dokumenti, https://dijete.hr/dokumenti/ (01.08.2109).
} 
bodno izražavanje stavova o svemu što se odnosi na njega te pravo da njegovi stavovi budu uvaženi u skladu s dobi i zrelošću.

Učenje o ljudskim pravima trebalo bi započeti u djetetovoj što ranijoj dobi. Jedna od zadaća škole je poučavati o pravima, za prava i u pravima djeteta, tj. u ozračju u kojem se aktivno i svakodnevno žive i ostvaruju sva dječja prava. ${ }^{12}$ To je moguće »samo u demokratskom školskom i razredno-nastavnom ozračju«.13

Suvremene teorije škole govore o potrebi kvalitetne, humane i djelotvorne škole koja prepoznaje potrebu aktivnog uključivanja i sudjelovanja učenika u odgojnom i obrazovnom procesu te pokazuje iskren interes za učenikovo mišljenje, čime se u takvoj školi postižu kvalitetni obrazovni rezultati. Prevladavajućem načinu: »Obavi što brže, dobij željenu ocjenu i tjeraj dalje « ${ }^{14}$ suprotstavlja se spoznaja o važnosti samovrednovanja učenika, pri čemu - procjenjujući svoj rad, oni počinju voditi računa o kvaliteti i težiti još boljem. ${ }^{15}$ Iako su u ostvarivanju dječjih prava u Hrvatskoj postignuti pozitivni iskoraci, Nacionalna strategija za prava djece u Republici Hrvatskoj (RH) za razdoblje od 2014. do 2020. navodi da još ima prilično prostora za poboljšanja, između ostalog i na području »osvješćivanja o mjestu i ulozi djece u društvu te o davanju prioriteta pravima djece u odnosu na prava odraslih «. ${ }^{16}$ Izvještaj o radu pravobraniteljice za djecu iz 2018. pokazuje da se prava djece na sudjelovanje i uvažavanje mišljenja u hrvatskim školama još uvijek ne ostvaruju dovoljno.

»Rezultati istraživanja o participaciji djece u sustavu odgoja i obrazovanja koje smo proveli tijekom 2017. i 2018. godine, u kojem je sudjelovalo više od 2700 djece osnovnoškolske i srednjoškolske dobi, potvrdili su terenske uvide djelatnika pravobraniteljstva za djecu, a to je da se djecu ne uvažava dovoljno i da većinom odraslima nije bitno što djeca misle. Djeca nemaju dojam da njihovo mišljenje može dovesti do promjena u školi ili utjecati na ishod nekih odluka - rijetko ih se uključuje u raspravu o relevantnim temama jer odrasli često misle da za to nisu kompetentna. «17

Partnerski odnos nastavnika i učenika u zajedničkom donošenju odluka kod stvari za koje je to moguće i poželjno, na način primjeren učeničkim mogućno-

${ }^{12}$ Usp. Dubravka MALEŠ, Značenje odgoja i obrazovanja o pravima djeteta, u: Dubravka MALEŚ, Ivanka STRIČEVIĆ (ur.), Mi poznajemo i živimo svoja prava, Zagreb, Školska knjiga, 2003, 13-20.

${ }^{13}$ Milan MATIJEVIĆ, Prava djeteta u nastavnom procesu, u: Maleš, Stričević (ur.), Mi poznajemo i živimo..., 21-27, 27.

${ }^{14}$ William GLASSER, Nastavnik u kvalitetnoj školi, Zagreb, Educa, 1999, 81.

${ }^{15}$ Usp. isto; William GLASSER, Kvalitetna škola, Zagreb, Educa, 1994.

${ }^{16}$ MINISTARSTVO SOCIJALNE POLITIKE I MLADIH, Nacionalna strategija za prava djece u Republici Hrvatskoj za razdoblje od 2014. do 2020. godine (2014, 7), https://vlada.gov.hr/ pristupinformacijama/programi-strategije-planovi-i-izvjesca/strateski-dokumenti-vlade-rh/ ministarstvo-za -demografiju-obitelj-mlade-isocijalnu-politiku/17700 (01.06.2019).

${ }^{17}$ PRAVOBRANITELJ ZA DJECU RH, Izvješće o radu pravobraniteljice za djecu za 2018. godinu $(2018,6)$, http://dijete.hr/izvjesca/izvjesca-o-radu-pravobranitelja-za-djecu/ (20.07.2019). 
stima, u školama nije dovoljno razvijen ${ }^{18}$. Iskustva pokazuju da i ono sudjelovanje koje se ostvaruje, često nije odraz stvarne namjere nego je više formalne prirode da bi se naizgled poštivalo propise i ispunjavalo očekivanja. Tri su česta modela u kojima se prepoznaje prividna participacija djece:

»Manipulacija - djeca sudjeluju na način da ih se pita što misle te se njihove ideje iskoriste, ali pritom ne razumiju svoju ulogu, ni način na koji su njihove ideje upotrijebljene; dekoracija - djeca sudjeluju kako bi uljepšala neki događaj, ali ne razumiju koja je svrha njihovog sudjelovanja i tokenizam - djecu se pita za mišljenje, ali im se ne daje mogućnost izbora načina na koji će svoje mišljenje izraziti niti znaju u kojoj im je mjeri dopušteno iskazati svoje ideje.«19

Također, jedan od oblika prividne participacije djece jest situacija kada se djecu pozove na sudjelovanje i iskazivanje mišljenja da bi se potom to mišljenje u potpunosti ignoriralo i smatralo nevažnim.

Ukupno gledano, raskorak koji postoji između teorijski zamišljene participacije učenika u školi i primjene te zamisli u praksi, kao i nedovoljan broj podataka, istraživanja i teorijskih modela tog područja

»ukazuje na potrebu za daljnjim promicanjem dječje participacije u školi kroz znanstvene i stručne radove, participativne istraživačke projekte te interaktivne prikaze modela dječje participacije. ${ }^{20}$

\section{Glazbena škola}

Osnovne glazbene škole su specifične škole u hrvatskom obrazovnom sustavu jer nisu obavezne, pa je pretpostavka da će ih upisati djeca koja to žele, a budući da se kod upisa radi selekcija - pretpostavka je da će ih upisati djeca koja su prepoznata kao glazbeno nadarena. I dok je za neke učenike završetak osnovne glazbene škole kraj glazbenog obrazovanja, dio njih nastavlja obrazovanje u srednjoj glazbenoj školi, a dio upisuje druge srednje škole paralelno pohađajući i srednju glazbenu školu - gdje u tom slučaju slušaju samo stručne, glazbene predmete.

Nastava teorijskih predmeta, zbora, orkestra i komorne glazbe u glazbenim je školama grupna, dok je nastava sviranja instrumenta ${ }^{21}$ individualna. Deset godina, ${ }^{22}$ od prvog razreda osnovne ${ }^{23}$ pa do četvrtog razreda srednje glazbene

\footnotetext{
${ }^{18}$ Isto, 50 i 185-187; Usp. Sandra CAR, Ivana JEĐUD BORIĆ, Participacija djece u školi, Školski vjesnik: časopis za pedagogijsku teoriju i praksu, 65 (1) 2016, 117-136.

${ }^{19}$ Roger HART, prema Ana MARKOVINOVIĆ, Participativna prava djeteta u sustavu odgoja i obrazovanja, Dijete i društvo, 12 (2010) 1/2, 117-128, 120.

${ }^{20}$ Sandra CAR, Ivana JEĐUD BORIĆ, Participacija djece u školi..., 117-136, 117.

${ }^{21}$ Pod instrumentom se u tekstu podrazumijeva i ljudski glas, tj. učenje pjevanja.

${ }^{22} \mathrm{Za}$ neke instrumente (npr. kontrabas, solo pjevanje...) učenje počinje kasnije, ovisno o fizičkim karakteristikama učenika, pa ukupno školovanje na predtercijarnoj razini može biti kraće.

${ }^{23}$ Osnovna glazbena škola za sviranje instrumenta u pravilu traje šest godina.
} 
škole, u nižim dvaput, a u višim razredima i više puta tjedno na satovima instrumenta uči se sviranje i glazba. ${ }^{24}$ Tumačenje djela i traženje načina sviračke interpretacije, najuspješnije se ostvaruje kao suradnički projekt učenika i nastavnika.

"Zajedničkim radom u razgovoru i raspravi, kroz traženje, pokušaje i pogreške, proučavanjem razdoblja, stila i kompozitora, preslušavanjem snimki različitih izvođača te pažljivom analizom notnog teksta - polagano (se) oblikuje ideja. Muzička ideja je kao živa materija, njezin oblik nikad nije konačan, ona sazrijeva, živi, razvija se i mijenja, pa se s vremenom mijenja i interpretacija. Iskusnim nastavnicima tu ne predstavlja problem da s različitim učenicima rade drugačiju interpretaciju istih glazbenih djela, prilagodivši se time osobnosti i senzibilitetu svakog učenika, istovremeno ne narušavajući ni kompozitorove zamisli ni kvalitetu izvedbe. $\aleph^{25}$

Nametanje ideja i stavova učeniku, pri čemu postoji samo jedan, nastavnikov način te nastava gdje je poruka "tako se to svira, a sve drugo je krivo", također je prisutno u glazbenim školama. Pod krinkom višeg umjetničkog cilja i u uvjerenju da će učenik jednog dana možda i biti dorastao da nešto osmisli i izabere - ali da za to danas još nije sposoban, nastavnici tog stila neće učeniku omogućiti sudjelovanje i izražavanje mišljenja niti će uvažiti eventualno izrečeno mišljenje. Takva nastava sviranja sputat će kreativnost i uspavati maštu učenika te je on za glazbu i umjetnost najčešće nepovratno izgubljen.

\section{Cilj i problemi}

Prvi je cilj ovog rada istražiti jesu li učenici i nastavnici glazbene škole upoznati s posebnim dječjim pravima kao dijelom općih ljudskih prava i slažu li se s njihovim postojanjem. Propitivanjem stavova učenika i nastavnika o pravima učenika, napose pravu na mišljenje i sudjelovanje u nastavi sviranja instrumenta u glazbenoj školi, drugi je cilj istraživanja utvrditi postoje li razlike u tim stavovima s obzirom na spol (između učenika i učenica; između nastavnika i nastavnica) i status ispitanika (između nastavnika i učenika).

Sličnosti i razlike stavova učenika i nastavnika te njihove eventualne primjedbe i prijedlozi, ukazat će na moguća poboljšanja ostvarivanja participativnih prava učenika u nastavnoj praksi, posebice nastavi instrumenta - što je i krajnji cilj ovog rada. Rad polazi od sljedećih hipoteza:

\footnotetext{
${ }^{24}$ Usp. MZOŠ, Nastavni planovi i programi za osnovne glazbene škole i osnovne plesne škole, Zagreb, HDGPP, 2006; MZOŠ, Nastavni planovi i programi za srednje glazbene i plesne škole, Zagreb, HDGPP, 2008.

${ }^{25}$ Davor BRĐANOVIĆ, Glazbene sposobnosti, osobine ličnosti i obilježja okoline kao prognostički pokazatelji razvoja glazbene kompetencije, Doktorska disertacija, Zagreb, UFZG, 2016, 16.
} 
H1: Područje specifičnih dječjih prava kao dijela općih ljudskih prava, učenici i nastavnici glazbene škole dobro poznaju.

H2: Postoje razlike između stavova djevojčica i dječaka o pravima učenika u glazbenoj školi, napose o pravu na mišljenje i sudjelovanje u nastavi sviranja instrumenta.

H3: Postoje razlike između stavova nastavnika i nastavnica o pravima učenika u glazbenoj školi, napose pravu na mišljenje i sudjelovanje u nastavi sviranja instrumenta.

H4: Postoje razlike između stavova učenika i nastavnika o pravima učenika u glazbenoj školi, napose pravu na mišljenje i sudjelovanje u nastavi sviranja instrumenta.

H5: Prava učenika na mišljenje i sudjelovanje u glazbenoj se školi ostvaruju.

\section{Uzorak i metoda}

U istraživanju provedenom tijekom 2018. godine, dobrovoljnom i anonimnom, sudjelovalo je 206 ispitanika - 53 nastavnika sviranja instrumenta i 153 učenika od 1. pripremnog do 4. razreda srednje Glazbene škole u Varaždinu (tablice 1, 2 i 3).

Tablica 1. Spol ispitanika

\begin{tabular}{|c|c|c|c|c|c|c|}
\hline & N & Nastavnici & Nastavnice & N & Učenici & Učenice \\
\hline Broj ispitanika & 53 & 23 & 30 & 153 & 76 & 77 \\
\hline
\end{tabular}

Tablica 2. Radni staž nastavnika

\begin{tabular}{|c|c|c|c|c|}
\hline & N & M & Min. & Maks. \\
\hline Godine staža & 53 & 17,74 & 1 & 43 \\
\hline
\end{tabular}

Tablica 3. Podjela učenika prema razredima

\begin{tabular}{|c|c|c|c|c|c|c|}
\hline Razred & 1. pr. & 2. pr. & 1. sš & 2. sš & 3. š̌ & 4. sš \\
\hline Broj učenika & 16 & 19 & 27 & 34 & 30 & 27 \\
\hline
\end{tabular}

Korišteni anketni upitnik osmišljen je za ovo istraživanje i ima dvije inačice - jednu za nastavnike i druga za učenike. U obje inačice pitanja su u biti ista da bi se u kasnijoj obradi odgovori mogli uspoređivati, no neka su prilagođena prema tome postavljaju li se nastavnicima ili učenicima. Nakon varijabli spola i dobi (razred učenika/radni staž nastavnika), tri su općenita pitanja kombiniranog tipa o dječjim pravima. U četrnaest pitanja drugog dijela upitnika od 
ispitanika se tražilo da na ljestvicama Likertova tipa s pet stupnjeva: 1=uopće se ne slažem, $2=$ uglavnom se ne slažem, $3=$ niti se slažem niti se ne slažem, $4=$ uglavnom se slažem i $5=u$ potpunosti se slažem - procijene razinu poštivanja prava učenika u glazbenoj školi. Svoje procjene i stavove ispitanici su zatim mogli pojasniti u zadnjem dijelu upitnika u pitanju otvorenog tipa. Tu su mogli dati i prijedloge eventualnih promjena i poboljšanja poštivanja učeničkih prava. U obradi dobivenih rezultata upotrijebljeni su standardni statistički postupci: frekvencija podataka, postotak, aritmetička sredina i t-test. Korišten je slobodno dostupan statistički program PSPP.

\section{Rezultati i rasprava}

Dobiveni su rezultati pokazali da $87(56,86 \%)$ anketiranih učenika glazbene škole $(\mathrm{GS})$ smatra potrebnim postojanje posebnih prava djece u odnosu na odrasle, a njih $66(43,14 \%)$ smatra da takva prava nisu potrebna. Za dokument koji štiti prava djece ne zna 131 (85,62 \%), a za dokument zna, ali ga ne navodi ili navodi krivo, 19 (12,42 \%) učenika. Naziv Konvencije o pravima djeteta znaju i navode točno samo $3(1,96 \%)$ učenika. Neka dječja prava zna i navodi 109 (71,24 \%) učenika, dok ni jedno pravo ne navodi njih 44 (28,76 \%). Najčešće spominju pravo na obrazovanje, iznošenje vlastitog mišljenja, igru, obitelj i sigurnost. Rezultati nadalje pokazuju da $35(66,04 \%)$ nastavnika GŠ iskazuje da su potrebna posebna prava djece u odnosu na odrasle, a 18 (33,96 \%) drži da takva prava nisu potrebna. Njih $16(30,2 \%)$ zna i navodi točno naziv Konvencije o pravima djeteta, $14(26,4 \%)$ zna za dokument, ali ga ne navodi ili ne navodi točan naziv, dok $23(43,4 \%)$ anketirana nastavnika ne znaju za taj dokument. Neka dječja prava navodi 30 (56,6 \%), dok $23(43,4$ \%) nastavnika ne navodi ni jedno dječje pravo. U anketi nastavnici najčešće spominju pravo djeteta na obrazovanje, sigurnost, zdravstvenu zaštitu, obiteljsku brigu i igru.

Dobiveni podaci ukazuju na potrebu edukacije učenika i nastavnika u području dječjih prava, primjerice o Konvenciji o pravima djeteta. Stoga prva hipoteza istraživanja - područje specifičnih dječjih prava kao dijela općih ljudskih prava, učenici i nastavnici glazbene škole dobro poznaju - nije prihvaćena.

Ukupni rezultati anketiranih učenika (tablica 4) pokazuju da oni poštivanje propitanih svojih prava u glazbenoj školi smatraju vrlo dobrim. Relativno visoko $(\mathrm{M}=3,97)$ procjenjuju ukupno poštivanje prava na mišljenje i sudjelovanje, pogotovo na satu sviranja $(\mathrm{M}=4,27)$. Istodobno relativno nisko procjenjuju da poštivanje učeničkih prava smanjuje autoritet nastavnika instrumenta $(M=1,86)$ jer - kada se poštuju prava učenika nastava sviranja je kvalitetnija $(M=3,80)$. Vrlo visoku procjenu slaganja u anketi $(M=4,78)$ učenici su dali tvrdnji - svako dijete ima pravo na glazbeno obrazovanje. Tvrdnja - znam kome se u GŠ mogu obratiti za pomoć u zaštiti mojih prava - dobila je relativno visoku procjenu 
$(M=3,79)$, a spomenuti valja i umjerene procjene učenika da u glazbenoj školi često zloupotrebljavaju svoja prava $(M=2,63)$ te da su im važnija prava od dužnosti (odgovornosti) - M=2,59.

Tablica 4. Stavovi učenika

\begin{tabular}{|r|l|c|c|c|c|c|}
\hline & \multicolumn{1}{|c|}{ Varijable (pitanja) upitnika } & N & $\begin{array}{c}\text { Aritmetička } \\
\text { sredina (M) }\end{array}$ & $\begin{array}{c}\text { Std. } \\
\text { devijacija }\end{array}$ & Min. & Maks. \\
\hline 1. & $\begin{array}{l}\text { Dječja prava na mišljenje i sudjelovanje u } \\
\text { glazbenoj se školi poštuju }\end{array}$ & 153 & 3,97 & 0,93 & 1,00 & 5,00 \\
\hline 2. & $\begin{array}{l}\text { Učenici u glazbenoj školi često } \\
\text { zloupotrebljavaju svoja prava }\end{array}$ & 153 & 2,63 & 1,11 & 1,00 & 5,00 \\
\hline 3. & $\begin{array}{l}\text { Svako dijete ima pravo na glazbeno } \\
\text { obrazovanje }\end{array}$ & 153 & 4,78 & 0,60 & 2,00 & 5,00 \\
\hline 4. & $\begin{array}{l}\text { Poštivanje učeničkih prava smanjuje } \\
\text { autoritet nastavnika instrumenta }\end{array}$ & 153 & 1,86 & 0,95 & 1,00 & 5,00 \\
\hline 5. & U GŠ učenici međusobno dobro surađuju & 153 & 4,23 & 0,76 & 1,00 & 5,00 \\
\hline 6. & $\begin{array}{l}\text { Učenicima GŠ važnija su prava od } \\
\text { dužnosti (odgovornosti) }\end{array}$ & 153 & 2,59 & 1,03 & 1,00 & 5,00 \\
\hline 7. & $\begin{array}{l}\text { Kada se poštuju učenička prava nastava } \\
\text { sviranja je kvalitetnija }\end{array}$ & 153 & 3,80 & 1,03 & 1,00 & 5,00 \\
\hline 8. & $\begin{array}{l}\text { Nastavnik instrumenta nerado odgovara } \\
\text { na moja pitanja }\end{array}$ & 153 & 1,41 & 0,90 & 1,00 & 5,00 \\
\hline 9. & $\begin{array}{l}\text { Znam kome se u GŠ mogu obratiti za } \\
\text { pomoć u zaštiti svojih prava }\end{array}$ & 153 & 3,79 & 1,28 & 1,00 & 5,00 \\
\hline 10. & $\begin{array}{l}\text { Ne znam kako nastavnik instrumenta } \\
\text { vidi moj budući svirački razvoj }\end{array}$ & 153 & 2,46 & 1,29 & 1,00 & 5,00 \\
\hline 11. & $\begin{array}{l}\text { Na satu sviranja slobodno iznosim svoje } \\
\text { mišljenje o nastavi i sviranju }\end{array}$ & 153 & 4,27 & 1,05 & 1,00 & 5,00 \\
\hline 12. & $\begin{array}{l}\text { Nastavnik mi ne obrazloži uvijek baš } \\
\text { svaku ocjenu koju dobijem iz sviranja }\end{array}$ & 153 & 2,25 & 1,31 & 1,00 & 5,00 \\
\hline 13. & $\begin{array}{l}\text { Na programu koji sviram uvijek je barem } \\
\text { jedna skladba po mom izboru }\end{array}$ & 153 & 3,35 & 1,40 & 1,00 & 5,00 \\
\hline 14. & $\begin{array}{l}\text { Moje mišljenje o sviranju nastavnik } \\
\text { instrumenta rijetko uvažava }\end{array}$ & 153 & 1,97 & 1,13 & 1,00 & 5,00 \\
\hline
\end{tabular}

Druga hipoteza - postoje razlike između stavova učenika i učenica o pravima učenika u glazbenoj školi, napose pravu na mišljenje i sudjelovanje u nastavi sviranja instrumenta - prihvaćena je samo za tvrdnju - učenicima GŠ važnija su prava od dužnosti (odgovornosti), o čemu se statistički značajno više izjašnjavaju učenici $(\mathrm{t}=2,03 ; \mathrm{p}=0,044)$ od učenica. Treća hipoteza - postoje razlike između stavova nastavnika i nastavnica o pravima učenika u GŠs, napose pravu na mišljenje i sudjelovanje u nastavi sviranja instrumenta - nije prihvaćena jer se statistička značajnost razlika rezultata prema spolu nastavnika nije pokazala ni na jednoj čestici upitnika.

Ukupni dobiveni rezultati anketiranih nastavnika (tablica 5) pokazuju da i oni pretežno visoko procjenjuju poštivanje propitanih prava učenika u glaz- 
benoj školi. Relativno visoko $(M=3,91)$ procjenjuju ukupno poštivanje prava učenika na mišljenje i sudjelovanje, pogotovo na satu sviranja $(M=4,45)$. Istovremeno, relativno nisko procjenjuju da poštivanje učeničkih prava smanjuje autoritet nastavnika instrumenta $(M=2,08)$. Dvije su prethodne procjene nešto više od procjena učenika na istim česticama upitnika, dok je kod tvrdnje - kada se poštuju učenička prava nastava sviranja je kvalitetnija - umjerena procjena nastavnika $(M=3,25)$ niža od učeničke.

Od rezultata nastavnika još se može istaknuti relativno visoka procjena slaganja $(\mathrm{M}=4,43) \mathrm{s}$ tvrdnjom da svako dijete ima pravo na glazbeno obrazovanje i s tvrdnjom da učenici znaju kome se mogu obratiti za pomoć u zaštiti njihovih prava $(M=3,53)$, umjerena procjena da učenici u glazbenoj školi često zloupotrebljavaju svoja prava $(M=2,85)$ te da su im važnija prava od dužnosti (odgovornosti) - $\mathrm{M}=2,70$.

Tablica 5. Stavovi nastavnika

\begin{tabular}{|r|l|c|c|c|c|c|}
\hline & Čestice (pitanja) upitnika & $\mathbf{N}$ & $\begin{array}{c}\text { Aritmetička } \\
\text { sredina (M) }\end{array}$ & $\begin{array}{c}\text { Std. } \\
\text { devijacija }\end{array}$ & Min. & Maks. \\
\hline 1. & $\begin{array}{l}\text { Dječja prava na mišljenje i sudjelovanje u } \\
\text { glazbenoj se školi poštuju }\end{array}$ & 53 & 3,91 & 0,93 & 1,00 & 5,00 \\
\hline 2. & $\begin{array}{l}\text { Učenici u glazbenoj školi često } \\
\text { zloupotrebljavaju svoja prava }\end{array}$ & 53 & 2,85 & 1,15 & 1,00 & 5,00 \\
\hline 3. & $\begin{array}{l}\text { Svako dijete ima pravo na glazbeno } \\
\text { obrazovanje }\end{array}$ & 53 & 4,43 & 1,01 & 1,00 & 5,00 \\
\hline 4. & $\begin{array}{l}\text { Poštivanje učeničkih prava smanjuje } \\
\text { autoritet nastavnika instrumenta }\end{array}$ & 53 & 2,08 & 1,22 & 1,00 & 5,00 \\
\hline 5. & U GŠ učenici međusobno dobro surađuju & 53 & 4,08 & 0,73 & 1,00 & 5,00 \\
\hline 6. & $\begin{array}{l}\text { Učenicima GŠ važnija su prava od } \\
\text { dužnosti (odgovornosti) }\end{array}$ & 53 & 2,70 & 1,12 & 1,00 & 5,00 \\
\hline 7. & $\begin{array}{l}\text { Kada se poštuju učenička prava nastava } \\
\text { sviranja je kvalitetnija }\end{array}$ & 53 & 3,25 & 1,07 & 1,00 & 5,00 \\
\hline 8. & $\begin{array}{l}\text { Odgovaranje na pitanja učenika na satu } \\
\text { uglavnom je gubljenje vremena }\end{array}$ & 53 & 1,57 & 1,03 & 1,00 & 5,00 \\
\hline 9. & $\begin{array}{l}\text { Učenici znaju kome se u GŠ mogu } \\
\text { obratiti za pomoć u zaštiti prava }\end{array}$ & 53 & 3,53 & 1,05 & 1,00 & 5,00 \\
\hline 10. & $\begin{array}{l}\text { Planiram svirački razvoj učenika ne } \\
\text { opterećujući ih s podrobnostima tog } \\
\text { plana }\end{array}$ & 53 & 3,47 & 0,97 & 1,00 & 5,00 \\
\hline 11. & $\begin{array}{l}\text { Na satu sviranja učenici mi slobodno } \\
\text { iznose svoje mišljenje o nastavi i sviranju }\end{array}$ & 53 & 4,45 & 0,72 & 2,00 & 5,00 \\
\hline 12. & $\begin{array}{l}\text { Ne obrazložim učeniku baš uvijek razlog } \\
\text { dobivanja svake ocjene }\end{array}$ & 53 & 2,19 & 1,23 & 1,00 & 4,00 \\
\hline 13. & $\begin{array}{l}\text { Barem jedna od skladbi programa koji } \\
\text { sviraju uvijek je po izboru učenika }\end{array}$ & 53 & 3,96 & 0,94 & 1,00 & 5,00 \\
\hline 14. & $\begin{array}{l}\text { Učenici nisu kompetentni za davanje } \\
\text { praktično korisnog mišljenja o sviranju }\end{array}$ & 53 & 2,53 & 1,19 & 1,00 & 5,00 \\
\hline
\end{tabular}


Nakon testiranja dobivenih rezultata t-testom za nezavisne uzorke, četvrta je hipoteza - postoje razlike između stavova učenika i nastavnika o pravima učenika u glazbenoj školi, napose pravu na mišljenje i sudjelovanje u nastavi sviranja instrumenta - prihvaćena.

Tablica 6. Razlike između procjena učenika i nastavnika

\begin{tabular}{|r|l|l|c|c|}
\hline \multicolumn{1}{|c|}{ Varijable (pitanja) upitnika } & \multicolumn{1}{|c|}{$\begin{array}{c}\text { Status } \\
\text { ispitanika }\end{array}$} & N & $\begin{array}{c}\text { Aritmetička } \\
\text { sredina (M) }\end{array}$ \\
\hline \multirow{2}{*}{ 3. } & Svako dijete ima pravo na glazbeno obrazovanje & učenici & 153 & 4,78 \\
\cline { 3 - 5 } & nastavnici & 53 & 4,43 \\
\hline 7. & $\begin{array}{l}\text { Kada se poštuju učenička prava nastava sviranja je } \\
\text { kvalitetnija }\end{array}$ & učenici & 153 & 3,80 \\
\cline { 2 - 5 } & nastavnici & 53 & 3,25 \\
\hline \multirow{2}{*}{ 10. } & $\begin{array}{l}\text { Ne znam kako nastavnik instrumenta vidi moj budući } \\
\text { Svirački razvoj }\end{array}$ & učenici & 153 & 2,46 \\
\hline $\begin{array}{l}\text { Planiram svirački razvoj učenika ne opterećujući ih s } \\
\text { podrobnostima tog plana }\end{array}$ & nastavnici & 53 & 3,47 \\
\hline \multirow{2}{*}{ 13. } & $\begin{array}{l}\text { Na programu koji sviram uvijek je barem jedna skladba } \\
\text { po mom izboru }\end{array}$ & učenici & 153 & 3,35 \\
\hline & $\begin{array}{l}\text { Barem jedna od skladbi programa koji sviraju uvijek je } \\
\text { po izboru učenika }\end{array}$ & nastavnici & 53 & 3,96 \\
\hline \multirow{2}{*}{ 14. } & $\begin{array}{l}\text { Moje mišljenje o sviranju nastavnik instrumenta rijetko } \\
\text { uvažava }\end{array}$ & učenici & 153 & 1,97 \\
\cline { 2 - 5 } & $\begin{array}{l}\text { Učenici nisu kompetentni za davanje praktično } \\
\text { korisnog mišljenja o sviranju }\end{array}$ & nastavnici & 53 & 2,53 \\
\hline
\end{tabular}

T-test je pokazao (tablica 6) da između procjena učenika i nastavnika postoje statistički značajne razlike kod 3., 7., 10., 13. i 14. tvrdnje upitnika. Iako relativno visoka, to što je prosječna procjena nastavnika kod 3. tvrdnje - svako dijete ima pravo na glazbeno obrazovanje, statistički značajno niža $(\mathrm{t}=2,34 ; \mathrm{p}=0,022)$ od procjena učenika na prvi pogled iznenađuje. Na to ipak ne treba gledati kao na negiranje prava na glazbeno obrazovanje već kao na posljedicu iskustva. Zbog različitog stupnja glazbenih sposobnosti učenje sviranja u glazbenoj školi pred pojedince može postaviti nesavladive prepreke i prouzročiti frustracije i odbojnost prema sviranju i glazbi. Ne bude li se bavio sviranjem, takvom će pojedincu život biti sasvim dobar, a prema glazbi će zadržati pozitivan stav. Vjerojatno su prilikom svojih procjena nastavnici sviranja dijelom imali to na umu. S druge strane, premda je $M$ učeničkih procjena vrlo visok, razlog izostanka očekivane jednoglasne potpore - valjalo bi dodatno istražiti.

Dobiveni rezultati t-testa - gdje učenici statistički značajno više od nastavnika procjenjuju da je za kvalitetu nastave važno poštivanje učeničkih prava $(\mathrm{t}=3,36 ; \mathrm{p}=0,001)$, dok nastavnici značajno više od učenika smatraju da omogućavaju učenicima ostvarivanje izbornosti sviračkog programa tijekom nastave $(\mathrm{t}=3,59 ; \mathrm{p}<0,001)$ te istovremeno značajno više nego se to i samim učenicima čini $(\mathrm{t}=5,99 ; \mathrm{p}<0,001)$ iskazuju da učenici nisu upućeni, tj. da ih ne upoznaju s 
planom njihova daljnjeg sviračkog razvoja - rezultat su različitih uloga učenika i nastavnika u školi i s tim povezane percepcije.

Uz suradnički odnos nastavnika i učenika, koji je u glazbenim školama prilično dobro razvijen, odnos majstor (nastavnik - onaj kojeg se sluša) i šegrt (učenik - onaj koji sluša) također je vrlo živ - i potreban. Ipak, uloge i suradnju trebalo bi još više približiti, a učenike još aktivnije uključiti u planiranje njihovog sviračkog razvoja.

Moje mišljenje vezano uz sviranje, nastavnik instrumenta rijetko uvažava - 14. je tvrdnja upitnika koju su učenici procjenjivali. Kada bi se i nastavnicima postavilo takvo pitanje - mišljenje učenika vezano uz sviranje rijetko uvažavam - dobivene procjene vjerojatno ne bi bile iskrene. Stoga je u upitnik za nastavnike uvrštena preformulirana tvrdnja - učenici nisu kompetentni za davanje praktično korisnog mišljenja o sviranju. Pretpostavka je da nastavnici koji smatraju da učenici nisu kompetentni za davanje mišljenja o vlastitom ili tuđem sviranju neće eventualno dobiveno mišljenje učenika ni uvažiti. Ako se prihvati istoznačnost, tj. mogućnost usporedbe dobivenih procjena nastavnika i učenika na opisanim tvrdnjama (tablica 6), uz relativno nizak $M$ procjena učenika, nastavnici statistički značajno rjeđe $(t=3,04 ; p=0,003)$ uvažavaju učeničko mišljenje o sviranju nego što to sami učenici percipiraju. To daje prostora dvojbi jesu li nastavnici GŠ uvijek iskreni kada naizgled prihvaćaju mišljenje učenika.

U posljednjem pitanju upitnika gdje su svoje procjene i stavove mogli detaljnije pojasniti, u većini danih primjedbi/prijedloga ${ }^{26}$ eventualnih promjena i poboljšanja poštivanja učeničkih prava u GŠ učenici navode da su zadovoljni (90) ili uglavnom zadovoljni (20) sadašnjom praksom ostvarivanja svojih prava te da ponekad (4) imaju i prevelika prava.

Od predloženih poboljšanja izdvajaju se tri. Učenici smatraju da treba poboljšati suradnju nastavnika i učenika, ali ne daju konkretne prijedloge (17), navode da im treba omogućiti više sudjelovanja i izražavanja mišljenja (9), u devet primjedbi ističu potrebu fleksibilnijeg pristupa učenikovoj interpretaciji i izboru literature, dok 13 učenika nije dalo mišljenje.

Budući da velika većina učenika - njih 114 - smatra da se njihova prava u GŠ poštuju, peta je hipoteza ovog istraživanja - prava učenika na mišljenje i sudjelovanje u glazbenoj se školi ostvaruju - prihvaćena.

Njeno prihvaćanje potkrepljuju i navodi nastavnika o ostvarivanju prava učenika u GŠ: 27 nastavnika nije dalo primjedbu/prijedlog pa je pretpostavka da su zadovoljni sadašnjom praksom. U 8 komentara nastavnici pišu da je sadašnja praksa dobra te ne bi ništa mijenjali. Oni nadalje navode da ostvarivanje prava ovisi o nastavniku i učeniku (4) i treba ga kod učenika osvijestiti (5). Učenici u GŠ imaju previše prava (2), prevelik je naglasak na pravima, a premalen na od-

\footnotetext{
${ }^{26}$ Svaki je ispitanik mogao dati više prijedloga/primjedbi.
} 
govornostima učenika (1). Ostvarivanje prava učeniku svakako treba omogućiti (3) uz fleksibilniji pristup (2) koji treba uskladiti na razini škole (2).

\section{Zaključak}

Dječja prava kao dio ljudskih prava osjetljivo su i važno pitanje. Pravima, kao i odgovornostima - što je često zanemareno, treba pristupati s jednakom pažnjom. Odgovornosti čine slobodu pojedinca da odlučuje i bira, poštujući pri tom prava i slobode drugih. ${ }^{27}$ Odgovornosti stoga omogućavaju ostvarivanje prava i sloboda na primjeren način te sve to zajedno čini nedjeljivu cjelinu.

Profesionalni aspekt traži od nastavnika instrumenta suradnički odnos s učenikom, što je jedan od osnovnih uvjeta za postizanje dobrih rezultata i uspješno poučavanje sviranja svakog glazbenog instrumenta. S druge strane, pravo je učenika da u nastavi aktivno sudjeluje. Pravila profesije i poštivanje dječjih prava ovdje se međusobno preklapaju i nadopunjavaju tako da je bilo za očekivati - što rezultati ovog istraživanja i potvrđuju - da se participativna prava učenika na nastavi instrumenta u glazbenim školama uvelike ostvaruju.

Dobiveni rezultati pokazuju da su učenici i nastavnici većinom zadovoljni ostvarivanjem dječjih prava u glazbenoj školi. Rezultati također pokazuju da s pojmovima i značenjem prava djeteta ni jedni ni drugi nisu dovoljno upoznati. Očito, potreban je snažniji rad na području prava (i odgovornosti) učenika u školi. Također, potrebno je još veće uključivanje učenika u planiranje njihova razvoja te, s obzirom na uzrast, u stalan suradnički razgovor s nastavnikom instrumenta o sviranju i interpretaciji.

Rad na poznavanju i poštivanju dječjih prava je kontinuiran proces, a odgoj i obrazovanje iz područja općih i specifičnih, u ovom slučaju participativnih prava djeteta, ne treba samo djeci i mladima nego i odraslima - njihovom nastavnicima, da bi svi dionici nastavnog procesa naučeno mogli uspješno primijeniti u praksi.

\footnotetext{
${ }^{27}$ Usp. Amnesty INTERNATIONAL, Prvi koraci: priručnik o odgoju i obrazovanju za ljudska prava, Zagreb, Amnesty International Hrvatske, 2000.
} 


\section{Davor Brđanović* \\ Attitudes of Music School Teachers and Students Towards the Respect of Students' Participation Rights in the Educational Process of Learning a Musical Instrument}

\section{Summary}

The focus of this paper are rights of music school students, in particular their right to participation in the educational process of learning a musical instrument and appreciation of their opinions in this regard. The study involved 206 respondents, 53 teachers and 153 students of Varaždin Music School. As many as $56.86 \%$ of the surveyed students and $66.04 \%$ of teachers think that it is necessary that there are special rights of children in relation to adults. Only $1.96 \%$ of students are aware of the Convention on the Rights of the Child $(85.62 \%$ are not familiar with it), compared to $30.20 \%$ of teachers $(43.40 \%$ are not familiar with it). A total of $28.76 \%$ of students and $43.40 \%$ of teachers are unable to quote any given children's right. The respondent male students have expressed that to them rights they have at school are more important than their duties (responsibilities), which is statistically significant higher if compared with the responses provided by female respondents. Another statistically significant difference between the attitudes of teachers and those of students has been noticed: every child has the right to music education, when the student's rights are respected the quality of teaching how to play an instrument is better (students have given higher estimates); students do not take part in planning their development of music playing skills, students always choose at least one piece they play, students' opinions regarding music playing are not taken into account (higher estimates given by teachers). Students and teachers are mostly satisfied with the exercise of children's rights in music school, although they are not sufficiently familiar with them, which points to the need for an additional effort in this field - with regard to both groups. Although children's rights in music school are largely respected, there is still room for improvement.

Key words: children's rights, collaborative teaching, music, music teaching, Varaždin Music School.

(na engl. prev. Silvija Avar)

\footnotetext{
* Davor Brđanović, PhD, research associate, piano teacher, Varaždin music school; Address: Kapucinski trg 8, HR-42000 Varaždin, Croatia; E-mail: davor.brdanovic@skole.hr.
} 